This item was submitted to Loughborough's Research Repository by the author.

Items in Figshare are protected by copyright, with all rights reserved, unless otherwise indicated.

\title{
Complete house furnishers: the retailer as interior designer in nineteenth- century London
}

PLEASE CITE THE PUBLISHED VERSION

http://dx.doi.org/10.1111/joid.12000

\section{PUBLISHER}

Wiley / @ Interior Design Educators Council

VERSION

AM (Accepted Manuscript)

\section{PUBLISHER STATEMENT}

This work is made available according to the conditions of the Creative Commons Attribution-NonCommercialNoDerivatives 4.0 International (CC BY-NC-ND 4.0) licence. Full details of this licence are available at: https://creativecommons.org/licenses/by-nc-nd/4.0/

\section{LICENCE}

CC BY-NC-ND 4.0

\section{REPOSITORY RECORD}

Edwards, Clive. 2019. "Complete House Furnishers: The Retailer as Interior Designer in Nineteenth-century London”. figshare. https://hdl.handle.net/2134/14903. 


\title{
COMPLETE HOUSE FURNISHERS: THE RETAILER AS INTERIOR DESIGNER IN NINETEENTH CENTURY LONDON
}

\begin{abstract}
This research paper considers the history of a particular moment in the development of the interior decoration/design business. Although the history of interior design practice has been well charted as 'art/design history', the business and professional history has been somewhat neglected, except for work on particular firms. The issues examined relate to four particular aspects. The first covers the distinctions between decorators, upholsterers, furnishers and architects and how these differences were reflected in the work undertaken. Related to this is a brief examination of why many architects ignored interior work. Secondly, is the nature of the customer base and how it reacted in response to changing social and economic factors. Thirdly, there are the issues of marketing and promotion which were aimed at a much wider audience than architects would expect, and finally a consideration of the house furnisher as a foundation for the development of the professional interior decorator/designer.

To address these issues, the paper offers an overview of the rise, maturity and change of the house furnisher as the most important contributor to the supply of interior design/decoration advice and products in the second half of the nineteenth century. By taking case studies of important players in the field, the paper will consider why architects gave up their role as arbiters of taste in interior works, and how the house furnishing businesses took over. This is of some interest as it not only explores an issue that still remains in the interior design world - the notion of who controls the work, but also explores the nature and pre-history of professional interior design service providers in the period.

Although the scope of this essay is potentially wide ranging, it is limited to the second half of the nineteenth century and focuses on London for its case studies. Through a consideration of primary sources, often using the trade press for commentaries, a sense of the contemporary issues is made. In addition, the recent work by scholars in the field is used to interpret the changes described.

As a foundation for the subsequent development of a profession, the house furnisher had laid a number of ground rules. Apart from the issue of the control of work, they encouraged the development of specialized knowledge, and they recognised the importance of training and education, and to some extent, exercised control of access to the industry.
\end{abstract}


Complete House Furnishers: The Retailer As Interior Designer In Nineteenth Century London

\section{COMPLETE HOUSE FURNISHERS: THE RETAILER AS INTERIOR DESIGNER IN NINETEENTH CENTURY LONDON}

From at least the $17^{\text {th }}$ century, retailers, or more specifically upholsterers, have had a long history of providing a wide range of coordinated goods and services for decorative interior schemes. ${ }^{1}$ During the second half of the nineteenth century this business reached its apogee as the market for such services expanded exponentially. For a period of time, certain of these retailers offered a full house furnishing and interior project management service, which would later become the domain of the interior decorator/designer.

This paper therefore considers the business of the 'artistic' retailer during the period $1850-1910$ as a precursor to the professional interior designer. It is argued that, following the widespread abrogation of responsibility for interior decoration by architects early in the nineteenth century, certain retail furnishers and decorators, in their role as middlemen within a creative economy, acted as coordinators of interior design projects and crucially had overall responsibility and control of the works undertaken. This role, not only as supplier but also as arbiter and advisor, was only gradually usurped by the rise of the decorators, of amateur specialist advisors and professionals. Only when these advisors became consultants rather than trades-people did the process of change from retail control to the professional interior designer begin. In 1922 the blurred distinctions were clear:

The interior decorator is not subject to [professional] rules. Here and there a man ekes out a living by furnishing decorative advice on a percentage basis and he may be regarded as a professional decorator, but nine-tenths and perhaps ninety-nine onehundredths of the work executed under the direction of decorators in this country every year is done by men with establishments which must be supported, like other business establishments, on a profitable basis, and who would not be able to live if they depended on a small commission ${ }^{2}$

The business and professional issues that this statement generates are linked to Grace LeesMaffei's suggestion that 'professionalization is attendant upon industrialization, specialization, the division of labour and interdependence, ${ }^{3}$ These aspects of development and change reflect some of the issues this paper raises in relation to the business and industry of interior decoration and design. The development of an industrial base, along with continuing hand crafts, the specialization of skills and the interdependence of trades all fed the process of professionalization that was eventually to come in the twentieth century.

\footnotetext{
${ }^{1}$ See Geoffrey Beard, Upholsterers and Interior Furnishing in England 1530-1840, (Cambridge: Yale University Press, 1997).

${ }^{2}$ Russell B. Herts, The art and business of interior decoration (Boston: Small, Maynard, c1922), 28.

${ }^{3}$ Grace Lees-Maffei 'Introduction: Professionalization as a Focus in Interior Design History', Journal of Design History, 21 no 1: (2008) 1-18.
} 
Complete House Furnishers: The Retailer As Interior Designer In Nineteenth Century London

Although the role and contribution of women to the professionalization of interior decoration has been explored in depth recently, ${ }^{4}$ the retail business aspect was an important strand of influence in its continuing commercial development of the supply of products and services and its control of the work related to interior furnishings and decoration. A number of questions arise when considering the business of the 'artistic' retailer during the period $1850-1910$ as a precursor to the professional interior designer. What was the business of retailers of interior designs and decorations? How did the distinctions between decorators, upholsterers, furnishers and architects work practically through the control of work? Were showrooms, model rooms and exhibitions simply marketing tools? The clientele were crucial in making distinctions, so who commissioned the various strata of decorating and furnishing businesses? How did these changes impact on the progress of the profession?

Through a number of case studies of important London-based decorators, furnishers and upholsterers operating in the period between architectural dominance and the rise of the interior designer, this paper will examine the developments and changes that supported the full-service retail furnisher as one of the key providers of complete interiors. The methods used to collect and analyze the data for these studies are based on specialised secondary sources but also on primary material drawn from a range of contemporary publications, including trade journals, magazines and newspapers, which give very particular insights into business customs and practices. The availability of these through searchable databases has opened up a veritable goldmine of information. ${ }^{5}$

\section{Changes in the supply of interior decorating and design services in the mid- late nineteenth century}

The movement from occupation to profession required a complex set of developments, so changes did not occur overnight. As Bridget May points out

The process of professionalization involved key steps, which could be taken in varying order. These steps included identifying and developing specialized knowledge; establishing training and educational requirements; controlling access to the profession through various means such as professional organizations and licensing; and monitoring performance and formulating professional behaviours, standards and ideologies. ${ }^{6}$

Professions grow from trades as they develop an infrastructure, so a distinction between professions and occupations are often a matter of degree. The differences are based on stage

\footnotetext{
${ }^{4}$ See for example: Grace Lees-Maffei, 'Professionalization as a Focus in Interior Design History', Journal of Design History (2008) 21 (1) 1-18

${ }^{5}$ In addition see also for example, particular company archives at The Archive of Art and Design (V and A Museum), City of Westminster Archives Centre, London Metropolitan Archives. For images see English Heritage, RIBA, V \& A Museum collections.

${ }^{6}$ Bridget May, 'Nancy Vincent McClelland (1877-1959): Professionalizing Interior Decoration in the Early Twentieth Century’, Journal of Design History 21, no.1 (2008), p. 61.
} 
Complete House Furnishers: The Retailer As Interior Designer In Nineteenth Century London

of development of the knowledge base, cultural authority, jurisdiction, and ethical standards as well as educational infrastructures. The idea that the structure and organisation of a profession is the historic base for many of them is not the major factor. Abbott argues that the key nature of a profession is its ability to take 'control of work'. ${ }^{7}$ Therefore inter-specialist competition was a determining factor in establishing the interior design profession. Here I am thinking of the distinction between architects, decorators, upholsterers and full-service retailers.

Attempts at professional distinction in Britain were realised early on in the nineteenth century. In 1834 architects established the Institute of British Architects to distinguish themselves from the 'building trade' especially, but they also seem to have alienated themselves from the interior. Only four years after the establishment of the Institute of Architects a commentator could write:

It is too much the practice with the architects of this country to neglect that branch of their profession which is chiefly concerned with internal embellishment, to such degree, in fact, that they seem hardly to recognize its title to be considered as belonging to their province, but willingly relinquish it to upholsterers and decorateurs, which latter class of artistes would not exist separately as an intermediate grade between architects and upholsterers, but for either the pride or the supineness of architects themselves, who leave others to find the taste, which, be it good or bad, must ultimately manifest itself within the buildings they have merely planned and constructed. ${ }^{8}$

The honorary secretary of the Institute, giving evidence to a Select Committee on Art and Design in 1836, was scathing in his criticism of his fellows. "In England, interior decoration is too generally confided by the employer to the mere house-painter, whose education does not fit him for the occasion." ${ }^{9}$ In 1839, a respected professional journal noted that 'In these days, the moment an architect has finished the shell of a building he is turned out, and it is consigned to the house-painter and the upholsterer, who rule unfettered' ${ }^{10}$

The anonymous author of an 1847 article entitled 'The Architect versus the Cabinet Maker and Others' summed up the issue: 'There cannot be refused to the man of taste [architect], when he looks on his Architectural-work marred and distracted by the wretched Decorator or Upholsterer, the justice of his complaint that the Decorator or Upholsterer ought to be at least his subjects, if not practically as regards design, incorporated in himself' ${ }^{11}$ Clearly, there was a considerable problem not only with roles, but also with the question of appropriate taste and education. One critic did consider the role of the interior decorator to be

\footnotetext{
${ }^{7}$ Andrew Abbott, The System of Professions: An Essay on the Division of Expert Labor, (Chicago: Chicago University Press, 1988).

${ }^{8}$ The Foreign Monthly Review and Continental Literary Journal, “On Architectural Decoration” 11, no 11, June 1839, 142.

9 'Minutes of the Select Committee on Arts and Principles of Design' reported in Mechanics Magazine, 693, 1836, 144.

${ }^{10}$ The Civil Engineer and Architect's Journal, March (1849), 12, 65

11 'The Architect versus the Cabinet Maker and Others', The Fine Arts Journal, February 13 ${ }^{\text {th }}$, (1847), 228.
} 
Complete House Furnishers: The Retailer As Interior Designer In Nineteenth Century London

valuable. It was the American architect and landscape designer, A. J. Downing, who saw interior decorators as a complement to the architect. In 1850 he wrote:

When a villa is designed by an architect, he generally superintends and directs the finishing of the interior; and in villas of considerable importance, interior decorators, who devote themselves to this branch of the profession, are called in to complete the whole, as the builder leaves it. Some of these ... possess talent enough to take an apartment or a suite of apartments, design and execute the decorations, and color, and furnish them throughout in any style. ${ }^{12}$

Nevertheless, the professional journals harked back to the past and lamented the architect's loss of control over the interior design work. In 1863, The Builder, actually a journal for architects, forcefully suggested that 'every opportunity should be taken to demonstrate the importance of interior decoration as a subject for the attention of architects themselves. All decoration is part of architecture; coloured decoration is predominantly concerned in the effect of most interiors; and architects should never have allowed the study and control of it to escape them. ${ }^{13}$ These attacks continued sporadically and resurfaced in a campaign published in The Builder in 1878. Stefan Muthesius suggests that 'The Builder's invectives [against the furniture trade] must be seen as an attempt to strengthen, [or indeed regain] the architectural profession's foothold as overlords in all matters of interior and furniture design'. ${ }^{14}$

The reality was a lot more complex than this suggests, but there was a schism between the design of architectural shells and the interior that even now has still not been resolved. ${ }^{15}$ In any event it is clear that the control of work for furnishings and interior design had partially/generally moved away from the architects' direct control to other parties.

Interestingly, in 1869 the Building News suggested that: 'The best and most truly economical plan for anyone about to decorate and furnish is to go to some respectable house combining both branches, give an idea of what he likes (having an estimate if he wishes) and wash his hands of the whole till it be finished. ${ }^{16}$ Even so there were distinctions.. The article went on to say...it will generally be found advisable, when anything beyond simple painting and papering is intended to employ men whose prime business is that of decoration rather than upholsterers who have added decoration to their original occupation, for it requires a much higher art-education to produce a good decorator than a good upholsterer'... ${ }^{17}$ The distinctions were important to this journal and the role of education as a characteristic of a profession was already clearly indicated. This education was not only in terms of interior

\footnotetext{
${ }^{12}$ Andrew Jackson Downing, The Architecture of Country Houses Including Designs for Cottages, Farm Houses, and Villas, (New York: D. Appleton \& Co., 1850), 405.

13“"The Architectural Exhibition”, The Builder, April $4^{\text {th }}$ (1863), 21, 237.

${ }^{14}$ Stefan Muthesius 'We Do Not Understand What Is Meant by a "Company" Designing': Design versus Commerce in Late Nineteenth-Century English Furnishing', Journal of Design History, 5. 2 (1992), 115

${ }^{15}$ See for examples Allison C. White 'What's in a Name? Interior Design and/or Interior Architecture: The Discussion Continues’, Journal of Interior Design xvii 35 No 1 (2009).

16 “Interior Decoration-The Drawing Room”, Building News, February $5^{\text {th }}(1869), 122$.

${ }^{17}$ Ibid.
} 
Complete House Furnishers: The Retailer As Interior Designer In Nineteenth Century London

work but was also related to the understanding of the client and their needs, wants and aspirations. The same article noted that a decorator

must be guided in a great measure by the money at his disposal and by the position of his customer. It stands to reason that objects which would be thoroughly in keeping in the apartments of a banker or leading physician may appear, in the residence of a pawnbroker or a retired butcher, simply snobbish, though they may be perfectly able to afford them; but it requires no little tact to give effect to such considerations without giving offence. ${ }^{18}$

This need for an understanding of the niceties of social structures was as important as the more practical knowledge of design, its materials and processes.

\section{Development and change in furnishing businesses}

The loss of control by architects over the decoration and furnishing of many interiors gave upholsterers and decorators an opportunity to expand the remit of their businesses. The link between trade, commerce and art and design was made by furnishing businesses in a number of ways. Firstly, by employing architects and designers for individual projects as well as for stock items, secondly by adding the word 'art' to their business title ${ }^{19}$ and thirdly, by demonstrating their artistic design credentials at exhibitions, in their showrooms and in publications. $^{20}$

In terms of interior design the concept of 'unity' in an interior project was, although not new, a key concept in the development of the role of the interior decorator/designer. Retail spaces offered clients examples of fully furnished and decorated model rooms that reflected the best of the company's efforts. In addition to these retail developments, prestige businesses also ensured they were represented at national and international exhibitions. For example, the 1878 Paris exhibition was a showcase for a number of these companies including Shoolbred \& Co; H \& J Cooper; Gillows; Johnstone and Jeanes; Cottier and Co; Gregory and Co; Holland \& Sons; Jackson \& Graham; Charles Mellier; Trollope and Sons; and William Watt. All these firms were high class retail decorators and furnishers who were able to design and supply a unified interior scheme.

In the same year, 1878, Jules Lessing in his Berichte von der Pariser Weltaustellung commented favourably on the showrooms of London and Paris that supplied everything for the home and its interior. In addition he noted the fact that these retailers 'manage to link the individual trades together in a unified achievement. ${ }^{, 21}$ This business type was described in

\footnotetext{
${ }^{18}$ Building News $12^{\text {th }}$ February (1869), 143.

${ }^{19}$ See for example Christopher Dresser's 'Art Furnishers' Alliance': William Watt's 'Art furniture', and 'Morris \& Co., Art Decorators, Art Furnishers, Manufacturers and Designers’.

${ }^{20}$ This was no doubt a reflection of the interest in the fashionable Aesthetic and Household Art movements.

${ }^{21}$ Cited in Stefan Muthesius, The Poetic Interior, (London: Thames and Hudson, 2009), 39.
} 
Complete House Furnishers: The Retailer As Interior Designer In Nineteenth Century London

1988 by Pat Kirkham as the' comprehensive manufacturing firm' ${ }^{22}$ This seems to be a great example of the concept of the control of work that was crucial to the development of a profession. Although Kirkham emphasised the combination of crafts for furniture-making in all its forms, it is clear that many of these businesses were also full-service furnishers and interior decorators. This meant that the top class retailers employed skilled builders, joiners, plasterers, textile designers, fine artists and furniture designers, as well as engineers and technicians. In addition, these retailers responded to the growing demand for commercial and contract interior work for interiors such as offices, hotels, and public buildings. (See further below) The apparent professional standing of these people was clearly in the mind of the anonymous author who wrote in the magazine House Furnisher (1873) that 'your true upholsterer is a man of the most varied and important qualifications, and is often as necessary and as trusted an agent in many homes as are the family lawyer and doctor. ${ }^{23}$

The growth in demand for home furnishings and decoration in the late $19^{\text {th }}$ century meant that the market was also ripe for a different form of segregation. The distinction between piecemeal purchasing of single items for individual's own decorative schemes and contracting for a complete unified interior was a clear marker of status and identity. Indeed many firms published lavish catalogues which offered a wide variety of visually unified examples. In addition, they often included estimates appropriate to the house type being furnished, which ensured expenditure was both appropriate and manageable. ${ }^{24}$ This advertisement from Smith’s Warerooms, Clerkenwell, London, circa 1850s, explains the unwritten hierarchy: 'Those about to marry should obtain the improved book of estimates... where they will find a four-roomed cottage can be completely furnished for 23 guineas; a six-room house completely and neatly for £70; an eight-roomed house with many elegancies and substantialities for $£ 140$; and a mansion of fourteen rooms furnished with that style, beauty and durability...for 35 guineas. ${ }^{25}$ A different angle on these issues was described in the trade press.

In December 1900, an article in The Illustrated Carpenter and Builder pointed out that 'Until recently when a man wanted to furnish he would visit all the dealers and select piece by piece of furniture... . Today he sends for a dealer in art furnishings and fittings who surveys all the rooms in the house and he brings his artistic mind to bear on the subject. ${ }^{26}$ This set of comments looks like an acknowledgement of the growing professional status of the interior decorator/ designer.

\footnotetext{
${ }^{22}$ Pat Kirkham, The London Furniture Trade 1700-1870, (London: Furniture History Society, 1988), Chaper.5.

${ }^{23}$ House Furnisher, (1873). It is of interest that this metaphor was also used by the Garret sisters in their work House Decoration, published in 1876, where they said that 'Decorators may be compared to doctors. It is useless to put yourself under their direction unless you mean to carry out their regime', (p. 9-10)

${ }^{24}$ Clive Edwards 'Furnishing a Home at the Turn of the Century: The Use of Furnishing Estimates from 1875 to 1910’ Journal of Design History, 4, no. 4 (1991), 233-239.

25 Jane Dunbar, Early Victorian Woman, (London: Harrap, 1953), 40-41.

${ }^{26}$ The Illustrated Carpenter and Builder, Dec $7^{\text {th }}$ (1900), Supplement, 2.
} 
Complete House Furnishers: The Retailer As Interior Designer In Nineteenth Century London

\section{Case Studies of full -service retail furnishers/interior decorators}

In the 1882 Post Office London Directory there were listed eighty (80) businesses under the specific heading of 'Interior Decorators'. The most prestigious companies operating as complete house furnishers and decorators at the time were listed under that heading, but they were also to be found listed as upholsterers or on occasion, cabinet-makers. In order to locate these businesses in the development of the profession of interior decorator/designer, they have been divided into four groups.

\section{Elite suppliers (e.g. Royal commissions)}

There were a group of elite suppliers or as the Furniture Gazette put it 'high class houses, represented by such firms as those of Gillows, Morant, Dowbiggin \&c., whose reputation is such for the superiority of their productions that it is not necessary for them to make any [window] display whatsoever'. ${ }^{27}$

The Lancaster and Oxford Street, London based firm of Gillows (1769-1897) was one of the most prestigious companies of upholsterers, furnishers and decorators.

Their many decorating and furnishing commissions included landmark projects such as the Midland Grand Hotel at St Pancras railway station between 1868 and $1874,{ }^{28}$ the London Law Courts, the Palace of Westminster, as well as many other contracts world-wide. They employed some of the most well-known designers of their age including Bruce Talbert, T. E. Collcut and E.W. Godwin. Like other businesses of their ilk, they displayed work at national and international exhibitions. The acclaim they received was well publicised and, to a degree, confirmed their status. A report on their display at the Manchester Art Exhibition 1882, suggested that "the exhibit of Gillows is intended to illustrate generally the best and most costly art that can be called into the production of furniture and decoration, and it proves that in this country we have a firm equal to the occasion. ${ }^{29}$ Fig $\mathbf{1}$ here Figure 1 shows one of their commissions for a scheme for an octagonal room. The presentation of an exploded elevation follows an early eighteenth century model of visualisation that is representative of the watercolour layouts that were intended to show clients the overall design with details of woodwork, drapery and colour scheming. These types of drawings were used to sell schemes and should not be confused with watercolours made to record the style and details of established rooms. Not surprisingly the emphasis is on the design of the drapery, but there is also an attempt to show the furniture layout within the space.

In a twist, this elite firm turned into a major retail business in a merger with Warings, becoming Waring and Gillow in 1897. This business then transformed itself into a successful interior decoration department store.

Another old-established business that was often entrusted with the total control of the furnishing and decoration of interior works was Morant. The firm, originally described as a

\footnotetext{
${ }^{27}$ Furniture Gazette, $2^{\text {nd }}$ October (1875), 193.

${ }^{28}$ Laura Microulis, 'Gillow and the furnishing of the Midland Grand Hotel', The Magazine Antiques (1971), 165 no. 6 (June 2004) 108-17.

29 'Messrs Gillow \& Co’s Furniture’, The Lancaster Gazette and General Advertiser for Lancashire, Westmorland, and Yorkshire, Saturday, December 2nd, (1882).
} 
Complete House Furnishers: The Retailer As Interior Designer In Nineteenth Century London

'Paper Hanging Warehouse', was founded in 1790 by George Morant (1770 - 1846) at 88 New Bond Street, London. By 1819 they were recorded as 'Ornamental Painter and Paper Hanging Manufacturers'. By 1825 they had expanded to include carving, gilding and pictureframing for which they received a royal warrant. The kudos of this connection ensured commissions for various country houses. In a classified guide to London published in 1851 the company was recommended 'For an exhibition of specimens of furniture and decorations. Mr. Morant has been engaged in furnishing and decorating the mansions of the Dukes of Sutherland, Cleveland, Rutland, Norfolk, Buckingham, Devonshire, the Marquis of Exeter (for the Queen's visit), and other castles and mansions, at each of which specimens are to be seen' ${ }^{30}$ The firm became Morant \& Co in the 1850s, and in 1912 merged with Francis Lenygon to become the celebrated decorators, Lenygon \& Morant. ${ }^{31}$

The third example in the elite group is Holland and Sons. Founded c 1815, Holland and Sons were one of the largest furnishing enterprises of the nineteenth century. As with a number of other upholsterers and cabinet-making businesses, this firm had a relationship through family with a building concern in this case, Copland, Rowles and Holland. ${ }^{32}$ This type of connection was clearly of some value for businesses that claimed to be able to deal with all aspects of furnishing, interior decoration and equipment. By 1852 the company employed over 350 staff, as well as having extensive retail and manufacturing premises.

Their success was evident in the range of commissions for interior decorative work and furnishings they undertook. The firm was an important contractor for government business, including works for the Palace of Westminster. They undertook commercial commissions for the Great Western Railway and the Royal Academy of Arts as well as the interior decoration for a number of London' s gentlemen's clubs. In addition they carried out projects for the Royal Family which included work at Osborne House, Windsor Castle, Buckingham Palace, and Balmoral. ${ }^{33}$

Although they worked closely with many notable designers including Sir Charles Barry, Gottfried Semper, J. K. Collins, Henry Whitaker, and G. E. Street, they complained about the lack of trained designers: 'The principal impediments to the progress of the manufacture of elegant cabinetmaker's work in this country are caused by a great want of designers, draughtsmen, and modellers; in fact, of all the directors of art. The very few who can assist demand and are paid such excessive rates, that their services are dispensed with, except upon important occasions'. ${ }^{34}$

Clearly this issue of professional training was a serious worry. A very revealing comment about education in the trade is found in the following passage where, in 1863, the Committee of Council on Education took evidence from Holland's about the value of art education to the decorating trade:

\footnotetext{
${ }^{30}$ The British Metropolis, 1851, (London: Virtue and Co), 226.

${ }^{31}$ See further Francis Henry Lenygon and Jeannette Becker Lenygon architectural records and papers, circa 1910-1967, Avery Architectural Library.

${ }^{32}$ See Amanda Girling-Budd, Holland and Sons: a nineteenth century cabinet-making firm and its clients $1835-$ 1885, PhD, Royal College of Art, 2006.

${ }^{33}$ Edward T Joy, 'Holland \& Sons and the furniture of Osborne house' The Magazine Antiques (1971) 99, (April 1971), 580-5.

${ }^{34}$ Matthew D. Wyatt Reports on the Paris Universal Exhibition Part I, (London 1856), p.311
} 
Complete House Furnishers: The Retailer As Interior Designer In Nineteenth Century London

In answer to the question as to "the practical value of the art instruction given in the schools, state:" "We find those workmen who have studied at the School of Art so considerably in advance, that we have much less trouble with them in directing, having acquired a knowledge of style, which is essential in our business. We would much rather employ workmen who have received instruction there, it being a recommendation. We insist upon all our apprentices attending during their apprenticeship. It is most valuable to us and all engaged in architectural and ornamental decoration”. ${ }^{35}$

This was an early recognition of the value of education to a professional body of knowledge.

The last example in this group is the firm of Crace who were arguably the preeminent firm of 'architectural decorators' in 19th century Britain. Established in 1768 the firm remained a family business for over one hundred and thirty years. Their exclusivity in discreet showrooms, (decorated in a French Renaissance style) in Wigmore Street separated them from the more commercial centres of trade. Fig $\mathbf{2}$ here The style of their work can be seen in figure 2, a detailed perspective watercolour design depicting the planned colour scheme and detail of the staircase for the Institution of Civil Engineers. This approach to designs spaces was clearly architectural in tone and based on their scholarship of polychrome decoration.

The body of knowledge they acquired was a very important asset that they generously shared with the trade on a number of occasions via lectures. ${ }^{36}$ John Dibblee Crace (1838 1919), worked on schemes in several styles but his work was predominantly influenced by his studies of Italian Renaissance art. In 1919, J.D. Crace's academic credentials were confirmed when he published an important reference work entitled The art of colour decoration; being an explanation of the purposes to be kept in view and the means of attaining them. The learned nature of the firm's principal and the value of education to the profession of decorator was again noted by Matthew Digby Wyatt:

That Mr. John Gregory Crace has successfully studied the history and practice of his art is proved by his contributions to the transactions of the scientific societies of London, as well as by the works which he has carried out, some of the principal of which, in the Italian style, have been executed for the Duke of Devonshire, at Devonshire House, Chatsworth, and Lismore Castle ; and for the Marquis of Breadalbane, at Taymouth Castle ; his connexion with Sir Charles Barry and the late Mr. Pugin at the Houses of Parliament proves his competency for the successful treatment of mediaeval art." ${ }^{37}$

\footnotetext{
${ }^{35}$ Tenth Report of The Science and Art Department of The Committee of Council on Education, (London, 1863), 161.

${ }^{36}$ For a valuable discussion of one particular Crace project, see Megan Aldrich, and Barry Shifman, 'Crace, Pugin, and the Furnishing of John Naylor's Leighton Hall', Furniture History, 41, (2005) 117-87.

${ }^{37}$ Matthew D. Wyatt, Reports on the Paris Universal Exhibition Part I, (London, 1856), 309.
} 
Complete House Furnishers: The Retailer As Interior Designer In Nineteenth Century London

The value of education for interior work was not lost on contemporaries. In 1869, The Building News discussed the decorations of Sir Morton Peto's Kensington home and chastised the upholsterers Jackson and Graham (see below) for the quality of their interior decoration work. They then wrote that: 'Had a firm essentially decorative, such as Messrs. Crace, for instance, been employed, the beauties of the internal architecture would have been brought out by the decorative treatment, while the furniture would probably have been quite as good as that actually supplied. ${ }^{38}$ The distinction between the upholsterer and the decorator was clearly made.

\section{Specialist furnishers and decorators:}

As early as 1800 the upholsterer was reported as being the person who

tells one immediately what colours go together, how much each article costs, what one must choose in order to guard against the shape and style becoming old-fashioned after some years, what changes must be made in a house, what sort of carpet to go in the dining room and what sort in the dressing room, what materials last longest; how much time he needs to furnish the whole house and so on and so on. ${ }^{39}$

This reflects the importance of an understanding of the body of knowledge associated with a trade or profession as well as recognition of the skills acquired by upholsterers and later, interior decorators. Most importantly, it demonstrates the control over the works to be undertaken. The Furniture Gazette described these specialist furnishers and decorators as 'famous for the production of articles of high artistic order, of whom Jackson and Graham are a fair representative house. Their windows are never crowded with goods, but exhibit frequently one article only, rarely more than two or three, but these are always distinguished for some rare excellence of design or colouring.' 40

Thomas Charles Jackson and Peter Graham established the partnership of Jackson and Graham, trading at 37 Oxford Street, London, in 1836. ${ }^{41}$ On their trade card of about 1839 they were already described as 'Upholsterers, Carpet Manufacturers, Furniture Printers and Interior Decorators.' By 1866, the firm designated itself more ambitiously as 'upholsterers, cabinet-makers, carpet manufacturers, interior decorators and importers of French silks, bronzes and ornamental furniture.' ${ }^{42}$ This was a prime example of the merging of the roles of upholsterer, decorator and complete house furnisher. Their commissions included works for the Sultan of the Ottoman Empire, Napoleon III, the Grand Khedive at Cairo, Queen Victoria, and the Royal Palace in Siam. More mundanely, local hotel work included the Charing Cross Hotel, and the Langham Hotel. Fig 3 here

\footnotetext{
38 The Building News and Engineering Journal, Volume 16, 1869) 121.

${ }^{39}$ Kirkham, 1988, 67.

${ }^{40}$ Furniture Gazette, $2^{\text {nd }}$ October (1875), 193.

${ }^{41}$ The Times, $16^{\text {th }}$ May (1882), 11.

42 Clive Edwards, ‘The firm of Jackson and Graham', Furniture History, 24, (1998), 239.
} 
Complete House Furnishers: The Retailer As Interior Designer In Nineteenth Century London

Figure 3 demonstrates how retail furnishers and decorators marketed themselves and their products. In 1884 Jackson and Graham employed the architect R.W. Edis to create a display of a model bedroom for them at the International Health Exhibition, held in London in that year. This exhibit demonstrated their concern with contemporary issues around healthy living through the use of fitted furniture, it also helped to promote the firms services as complete interior designers and suppliers. This image was actually reproduced in the trade journal titled British Architect interestingly subtitled A journal of architecture and accessory arts' which demonstrates the close links between architects and interior furnishers.

As has been shown above, the collaboration of trained designers with these sorts of firms was commonplace. Owen Jones’s, Bruce Talbert's and Christopher Dresser's successful relationship with Jackson \& Graham is a prime example. Even though the firm employed distinguished designers, the architectural press still played out the arguments about the loss of control of work from the architect to the 'upholsterer'. Discussing the decorations of Sir Morton Peto’s Kensington home in 1869, The Building News wrote that:

The decorations were unfortunately taken out of the architect's hands and given, together with the furnishing, to Messrs. Jackson and Graham, a firm of upholsterers whose reputation for the quality and artistic excellence of their goods stands deservedly high, but whose notions of decoration appear to consist in the indiscriminate application of Mr. Owen Jones's objectionable crudities. In the case we refer to the delicate Italian modelling of the plaster ceiling appeared cheek by jowl with coarse quasi-Moorish flat ornaments, and the whole rejoiced in the tender colouring which graces St. James's Hall and the buffet at the Charing Cross Station! ${ }^{43}$

This criticism did not harm the firm; rather it was changes in the economy and the social hierarchy that meant that businesses without strong and progressive leadership would fall. Peter Graham retired in 1877 and by 1882 the firm was bankrupt.

A second example of the speciality firm is the partnership of Alfred Thomas Wright and George Needham Mansfield, who, during 1861, took over the business of their erstwhile employer, Samuel Hanson in New Bond Street. Like Holland and Sons there was a valuable connection to a building company in that George Mansfield was the son of George Mansfield senior, a building contractor. Success in both the 1862 London and 1867 Paris Exhibitions ensured that they were noticed and their work became synonymous with a revival of an Adam style of interiors. However, as was the case for a number of their fellow businesses, 1870 marked the beginning of the decline of this type of business as new, more vigorous enterprises gradually took over much of the trade. Their partnership was dissolved in late 1884.

Whilst these two firms were generally reproducing classic eighteenth century designs, another business saw a market for 'new art' furnishings and interiors. The partnership of

43 “Interior Decoration-The drawing room”, The Building News and Engineering Journal, 16, (1869), 121. 
Complete House Furnishers: The Retailer As Interior Designer In Nineteenth Century London

Collinson and Lock started as a cabinet-making concern but the scope of the company soon developed, so by 1882 they were described as 'upholsterers, decorators, paperhangers, manufacturers of artistic furniture and constructive woodwork for interiors and paper hangings of special design and colour.' ${ }^{44}$ Jane Panton praised the firm's interior decoration skills in her advice book From Kitchen to Garret: 'Could we afford it of course, I would employ Morris or Smee's people or Collinson and Lock, with their delicious arrangement of 'fittings', but we cannot'. ${ }^{45}$ Fig 4 here

Collinson and Lock were associated for much of their career with the design avantgarde (e.g. E.W. Godwin designed furniture for them) but they also had a special relationship with the theatre. Fig 4 clearly demonstrates this niche market with the eclectic 'aesthetic' scheme they supplied to Charles Kettlewell and his wife Edith Woodworth who was a celebrated stage actress. Firms were often identified with a particular approach to designed space and this space demonstrates Collinson and Lock's initial commitment to the business of 'art' furniture and furnishings. In this case references to Japonisme, chinamania and taxidermy combine with plasterwork ceiling and wall panelling to create an artistic interior.

Like Jackson and Graham above, the firm's interior 'fittings' were on show at the International Health Exhibition London: "In the class of fittings and accessories, and completely-fitted apartments, Messrs. Collinson and Lock (377) show two handsomely furnished model apartments .... One of the apartments, a drawing-room, is hung with a rich scarlet silk damask, the ceiling is panelled in fibrous plaster. A white chimney- piece in the corner, with hooded overmantel, and a white enamelled pianoforte in a rich Louis Seize style of decoration, besides some beautifully executed specimens of rosewood furniture, delicately inlaid with ivory'. ${ }^{46}$ Like the others before them, this firm suffered most from the combined effects of an economic downturn affecting wealthy clients, as well as a rise in the provision of interior furnishing services by department stores and very large furniture businesses. Their business was wound up in 1897 and absorbed by the now all-prevailing S. J. Waring and Co.

A slightly different example is the firm of George Trollope \& Sons. Initially a business of decorators and wallpaper suppliers established in 1778, by the mid-nineteenth century they had introduced a variety of house building and decorating trades to their portfolio. They were recorded in West Halkin Street, Belgravia by 1864 but did not operate a retail store. Their chief in-house designer was George T. Robinson. Although an architect by training, from the 1880s he committed himself to interior design, with much of his work being undertaken for ocean liner projects. ${ }^{47}$ Fig 5 here

Like a number of other elite interior decorating businesses Trollope's premises were quite discreet and were located away from the main retail thoroughfares. This gave a degree of exclusivity but still allowed examples of the firm's work to be displayed in room settings. Judging from the extant images of the showrooms, (fig 5) the clientele were quite conservative, with schemes based on seventeenth and eighteenth century country house

\footnotetext{
${ }^{44}$ Post Office London Directory, (1882).

${ }^{45}$ Mrs Panton, From Kitchen to Garret (London: Ward, 1890), $7^{\text {th }}$ edition, 37.

${ }^{46}$ The Building News and Engineering Journal, 47 (1885), 246.

${ }^{47}$ Robinson also published a work on decorative plasterwork and wrote on decorative arts for The Manchester Guardian and the Magazine of Art.
} 
Complete House Furnishers: The Retailer As Interior Designer In Nineteenth Century London

styles. Whereas Collinson and Lock's clients came from the bohemian section of society, Trollopes were engaged by a clientele with conservative and traditional tastes represented here by the reproduction Jacobean furniture, seventeenth century style ceiling and woodwork and sets of armour.

The firm exhibited at several international exhibitions, and was highlighted in an 1856 report on the Paris Exhibition. Digby Wyatt noted that: “Trollope’s firm was_established in the year 1788, and they have been extensively employed as decorators and upholsterers under most of the eminent architects of the last fifty years.”" ${ }^{8}$ Lady Frederick [Lucy] Cavendish gives a tantalising glimpse of interior decorating practice in her diary entry for December 13, 1864: “Thence to our splendid mansion, No. 21 Carlton House Terrace, where we met my old Meriel and Mrs. Talbot, and Trollope, the builder-and-furnisher's man. And we have settled the whole painting of the house, chosen all the papers, and the principal grates, and discussed many other points. All I think most successful”. ${ }^{49}$ A description of a process familiar to interior designers both past and present.

\section{Large scale furnishing department stores}

The Furniture Gazette noted this class of business as being 'represented by such firms as Shoolbred and Co. Marshall and Snelgrove and Maple, [who] make magnificent displays, in their large well-arranged windows of resplendent carpets, rich curtains fabrics, and inlaid cabinet work. ${ }^{50}$ Fig 6 here

The patrons of this type of enterprise were drawn from the newly burgeoning middle classes who needed advice in matters of taste. The example of an interior supplied and fitted by the London firm of Hampton and Sons (fig 6) dates from 1889 and shows a strangely eclectic interior lobby that conforms to a contemporary taste but demonstrates some degree of individuality. The space is characteristic of the Queen Anne revival but with assorted accessories that express some artistic hand. The photograph was commissioned by the company and may well have been used in a portfolio to demonstrate their works.

Indeed many of these stores published lavishly produced catalogues that showed the products they sold but also illustrated images of suggested room interiors and combinations of furnishings. ${ }^{51}$ Many London department stores sold furniture and offered decorating advice in some degree or other, but it was the Tottenham Court Road that became the hub for this level of business. ${ }^{52}$ One example will stand for many: Maple's of Tottenham Court Road.

At their height in the 1890s Maple and Co could boast that "Apart from supplying the furniture and furnishings, they undertook every description of Artistic Decoration, Interior

\footnotetext{
${ }^{48}$ Matthew D. Wyatt, Reports on the Paris Universal Exhibition Part I, (London 1856), 308.

${ }^{49}$ http://ladylucycavendish.blogspot.com/2009/02/13dec1864-decorating-house.html.

${ }^{50}$ Furniture Gazette, $2^{\text {nd }}$ October (1875), 193.

51 See further Clive Edwards, 'Establishing stability: conforming to type in British house furnishings 18601910’ in McMahon and Myers, The Objects and Textures of Everyday Life in Imperial Britain, Ashgate forthcoming.

${ }^{52}$ Clive Edwards, 'Tottenham Court Road: The Changing Fortunes of London's Furniture Street, 1850-1950, The London Journal, Vol. 36 No. 2, July, 2011, 140-60.
} 
Complete House Furnishers: The Retailer As Interior Designer In Nineteenth Century London

Woodwork, Panelling, Painting, Electric and Hot Water Engineering and Sanitary work on latest scientific principles. ${ }^{53}$ The extent of Maple's work as furnishers and decorators can be seen both in their illustrious lists of clients as well as the services offered. Clients included the Russian Emperor, various princes and kings of European countries and provinces, the King of Siam, the Grand Vizier of Persia as well as the British royal family. As to services, the company offered to visit all parts of the United Kingdom and 'advise with intending purchasers as to decorative, structural and sanitary [plumbing] work, as well as interior fittings and every detail of modern furnishings ... a large staff of clever draughtsmen and designers are retained for the preparation of schemes and suggestive sketches'. ${ }^{54} \mathrm{An}$ architectural/interior design practice in all but name.

A few years later, in 1912, Maple's directors immodestly reported to their AGM that: 'In architectural and colour decoration, in design, in furniture and the domestic arts, in textiles and metal work, our studios in London, Paris and Buenos Aires are in every respect representative, and we venture to think, more effectively and artistically endowed for the competition of today than any other existing organisation in the world'. ${ }^{55}$ Although this hyperbole was for the benefit of shareholders, it does demonstrate the confidence of this retail sector of the interior decoration business and illustrates how they tended to usurp the more traditional firms mentioned above.

\section{Decorating/upholstery/antique companies}

A final, more specialist group were the antique and curio dealers who in addition to their services for collectors, offered exclusive interior decorating and design services. Referring to the early to mid nineteenth century taste for antique French styles, John Cornforth noted that "The Louis revival is a particular element in the history of taste, but it was important in the long run because it was probably largely responsible for the alliance between antique dealers and decorators that still remains strong'. ${ }^{56}$

Although there were a number of 'curiosity dealers' who also undertook decorative work, ${ }^{57}$ this was always a special and elite branch of the trade. An early example from 1864 is the business of Samson Wertheimer, 154, New Bond Street, who advertised as being a 'Bronze, Bronze, Ormolu, and Marqueterie Manufacturer, Cabinet-Maker, House-Decorator, and Dealer in China Curiosities and Antiquities'. ${ }^{58}$ The business of Frederick Litchfield of 28-39 Hanway Street, which was listed in 1885 as 'china and antique furniture dealers, importers of works of art, and upholsterers and decorators', demonstrates their approach. Of course, the famous businesses of Joseph Duveen, 181 Oxford Street ${ }^{59}$ and Marks Durlacher

\footnotetext{
${ }^{53}$ Hugh Barty-King, Maples, Fine Furnishers, (Quiller Press, London, 1992), 48.

${ }^{54}$ Maple and Co., 1905 Catalogue.

${ }_{55}^{5}$ Maple and Co., AGM, 191, cited in Barty-King, Maples, 95.

56 John Fowler, John Cornforth. English decoration in the 18th century (London: Barrie and Jenkins, 1974$) 55$.

${ }^{57}$ See Mark Westgarth, 'A Biographical Dictionary of Nineteenth Century Antique and Curiosity Dealers', Regional Furniture, XXIII . Regional Furniture Society. (2009).

${ }_{58}$ Advertisement in Debrett's illustrated peerage and baronetage of the United Kingdom , (London, 1864), 391

${ }^{59}$ Nicholas Penny, Karen Serres, 'Duveen and the decorators', The Burlington Magazine, 149 (June 2007), 4006.
} 
Complete House Furnishers: The Retailer As Interior Designer In Nineteenth Century London

Bros., 103, Oxford Street ${ }^{60}$ were amongst other illustrious specialists who dealt in exclusive interior projects. Fig 7 here

The interior in Fig 7 shows the drawing room in the prestigious house of Sir Charles Grant furnished with antique furniture, decorations and objets de vertu supplied by Duveen's company. His work for illustrious clients allowed him to create a showcase for the French antiques and decorative arts he sold. Eighteenth century French furnishings and interiors were used as a guide to 'good taste', a concept reinforced by publications such as Codman and Wharton's The Decoration of Houses (1897). Duveen's control over all aspects of an interior project that included liaison with architects, decorators and suppliers ensured he was an absolute arbiter of taste. Indeed he employed decorators such as White Allom of London, and André Carlhian and Lucien Alavoine in Paris, so as Penny and Serres suggest 'this had the advantage of putting him on an equal footing with his clients' ${ }^{61}$

Finally, mention needs to be made of Francis H. Lenygon who originally founded Lenygon and Co in 1904 and in 1909 merged with Morant and to form Lenygon and Morant. This firm worked in handsome eighteenth century premises at 31 Old Burlington Street (later 48 South Audley Street) as architectural decorators as well as antique dealers. ${ }^{62}$ This combination of antique dealer and decorator was the basis for the establishment of a number of similar businesses in the early twentieth century. ${ }^{63}$

\section{Developments}

During the early twentieth century, the supremacy of the retail business in interior decorating/design was beginning to be challenged. The rise of antique dealers who dabbled in interior work, the growing number of 'amateur' advisors and advice publications, and the art movement generally, all contributed to a diluting of the retailers' responsibility for interiors.

The demand for interior design services though was still there. The idea of furnishing to a planned design or 'system', with the clear inference of professional input from an artistically trained decorator rather than a fashionable vendor, had already been suggested in the late nineteenth century by Mary Haweis. She explained that

To make a beautiful and artistic room it is not sufficient to collect a mass of good materials and mix them together. You may spend a fortune at a fashionable decorator's and make your house look like an upholsterer's showroom; or you may fill your house with antiquities of rare merit and calibre, and make it look like an old curiosity shop; but it may be most unpleasing all the same. The furnishing ought to be carried out on some sort of system.... ${ }^{64}$

\footnotetext{
${ }^{60}$ See G. C. Williamson, Murray Marks and his friends, John Lane, 1919, also Clive Wainwright, 'A gatherer and disposer of other men's stuffe’ Murray Marks, connoisseur and curiosity dealer', Journal of History of Collections (2002) 14 (1): 161-176.

${ }^{61}$ Penny and Serres, 403.

${ }^{62}$ Elizabeth McKellar, 'Representing the Georgian: Constructing Interiors in Early Twentieth-Century Publications, 1890-1930’ Journal of Design History 20, no. 4 (2007) 325-344.

63 e.g. Thornton-Smith, Keeble and White Allom, all in London.

${ }^{64}$ Mrs. Haweis, The Art of Decoration, (London: Chatto \& Windus, 1881) 201.
} 
Complete House Furnishers: The Retailer As Interior Designer In Nineteenth Century London

She makes her meaning completely clear in this passage: "It is the delicate, practised perception which places such a colour here, such another there - which feels how to craftily mingle richness with paucity of colour, so as not to tire the senses ...This discrimination divides the born decorator from the mere purveyor of reigning fashions, the artist from the upholsterer". 65

The gradual change from a bourgeois arrangement of interiors that reflected a hierarchical arrangement of tradition, style and authority to a more personal and individual interior that was increasingly organised by a professional decorator/designer was becoming evident. Mrs Haweis explained that "One of my strongest convictions, and one of the first canons of good taste, is that our houses, like the fish's shell and the bird's nest, ought to represent our individual taste and habits”. ${ }^{66}$ Stores that had once developed to embody and reflect the 'official' categories of society through established and set styles gradually changed as these groupings moved with societal changes.

As if in response to Mrs Haweis's comments, it was in 1894, that a group of important decorators proposed an association that would encourage the development of decoration as a profession. The Incorporated Institute of British Decorators was registered on the 21st of January 1899. The trade press reported that 'The recently incorporated Institute of British Decorators have just elected Mr. J. D. Crace, as their president. At the first annual meeting, held the other day, it was stated that 174 decorators had become members of the institute... ${ }^{67}$

The question of admitting women as members was raised at this initial meeting, where it was generally agreed that, if qualified they ought to be admitted. In fact women were not admitted to the Institute until after World War I and they remained as a small minority membership group well into the $20^{\text {th }}$ century. Nevertheless the tide was swelling and by 1915 the Post Office London Directory listed 127 interior decoration businesses. The oldestablished companies such as Gregory, Hamptons, Holland, Litchfield, Maples, Morris and Trollop still existed with Shoolbred, Waring and Gillow, and Hindley now also being designated as decorators. Fig 8 here These firms increasingly used the room setting display technique to help customers to visualize the selection of products in a space or. In some cases actually set up a room to particular requirements. Fig 8 shows such a setting from 1899 with a 'tasteful' but seemingly eclectic mix of styles in the London showrooms of Shoolbred \& Co. This image of a retail space was commissioned by the journal Lady's Pictorial subtitled A newspaper for the home, with whom, Shoolbred had an advertising relationship.

Most interesting is the fact that there were a growing number of individuals trading as 'interior decorators', of which 10 of the 127 entries were women. ${ }^{68}$ Decorators were gradually becoming known as persons as much as companies.

\footnotetext{
${ }^{65}$ Mrs. Haweis, The Art of Decoration, 369.

${ }^{66}$ Mrs Haweis, The Art of Decoration, 23-4.

${ }^{67}$ British Architect, (1899), 51, p.239.

${ }^{68}$ Post Office London Directory, (1915), [Part 4: Trades \& Professional Directory], 1675.
} 
Complete House Furnishers: The Retailer As Interior Designer In Nineteenth Century London

\section{Conclusion}

This paper has argued that the complete house furnisher undertook the role of interior decorator/designer for much of the nineteenth century. By the opening of the twentieth century a number of causes shaped the beginning of a major change in the business of decoration and design.

Firstly, there was a decline of the traditional patron base (especially country house estates and large town dwellings), which was coupled with the rise of a smaller-scale domestic market for decorator services and the growth of a commercial contract sector. Secondly, there was a major change in the nature of the furniture business itself, which saw manufacturing further divorced from the retail operations, signalling the decline of the inclusive and comprehensive manufacturing and retailing business. Thirdly, the increasing specialization of particular skills and the growing interdependence of trades associated with the design and fitting of the interior all fed the process of professionalization. Fourthly, there was the development of individual, independent, often female, consultant decorators, who established themselves in the gap. Their professional autonomy meant that they were not tied to a particular source of material choices or manufacturer. Finally, the revival of interest by architects and designers in the interior from the early twentieth century tended to move the corporate interior work away for the retail sector towards interior architects and designers. Whilst all these factors brought about the decline of a once highly influential sector of the decoration and design business, they helped to lay the groundwork for the transformation from trade to profession. 